\title{
Teaching and learning nature of scientific knowledge: Is it Déjà vu all over again?
}

\author{
Norman G. Lederman ${ }^{*}$ and Judith S. Lederman
}

\begin{abstract}
This review traces the history of research on the teaching and learning of nature of scientific knowledge (NOSK), and its implications for curriculum and instruction. Initially, the complex rubric of NOSK is clearly conceptualized, while recognizing that there is no singularly accepted definition. As part of this conceptualization NOSK is distinguished from the body of scientific knowledge and science practices/inquiry, the latter of which is often conflated with NOSK. The empirical research on NOSK related to teaching, learning, and assessment is briefly reviewed, followed by a discussion of the challenges that teachers face and a delineation of research foci that can help alleviate teachers' challenges. Finally, a variety of important questions yet to be answered are delineated and explained.
\end{abstract}

Keywords: Nature of scientific knowledge, Scientific inquiry, Research on nature of scientific knowledge

\section{Introduction}

\section{Conceptualizing the construct}

There have been many changes in how nature of scientific knowledge (NOSK), also known as nature of science (NOS), not the least of which is the change in acronym to NOSK used here. To best understand NOSK and how it fits into the holistic picture of how it fits into research, practice, and science curriculum, it is important to briefly discuss what is meant by science. The question, "What is Science?" is deceivingly simple. There are many conceptualizations of science. The ceiling of the rotunda in the National Academy of Science in Washington, D.C. contains the following inscription: "To science, pilot of industry, conqueror of disease, multiplier of the harvest, explorer of the universe, revealer of nature's laws, eternal guide to truth. "The quote is not attributed to any individual and the building was built in 1936. It is not clear if the quote is older than 1936. Alternatively, Noble Prize winning physicist Richard Feynman defined science in the 1970s as "the belief in the ignorance of experts" (Feynman \& Cashman, 2013). Most recently, Arthur Boucot, a prominent paleobiologist, in a personal conversation characterized science as "an internally consistent set of lies designed to explain away the universe."

\footnotetext{
* Correspondence: ledermann@iit.edu

Illinois Institute of Technology, 3424 S. State St., Suite 4007, Chicago, IL 60616, USA
}

These statements are quite varied and, as provocative as Boucot's and Feynman's definitions may be, they are closer to how science is characterized in recent reform documents, such as the Next Generation Science Standards (NGSS Lead States, 2013) and the National Science Education Standards (National Research Council, 1996). At its core, science is a constructivist human endeavor as Kuhn's (1970) seminal work made quite clear. When considering the target audience of elementary, middle, and high school students, we must consider what "definition of NOSK is most developmentally appropriate and understandable.

Commonly, the answer to this question has three parts. First, science is a body of knowledge. This refers to the traditional subjects or body of concepts, laws, and theories, for instance, in biology, chemistry, physics etc. The second part refers to how the knowledge is developed. That is scientific inquiry (or what is referred to as "practices" in the NGSS). The third component, answering the question of "what is science?" is nature of scientific knowledge (NOSK). NOSK is commonly referred to as nature of science (NOS), but NOSK is more descriptive of what originally meant by the phrase (Lederman \& Lederman, 2014; Rubba \& Anderson, 1978). That is, NOSK refers to the characteristics of scientific knowledge that are derived from how the knowledge is developed (i.e., scientific inquiry). Current debates stemming 
from a family resemblance conceptualization of nature of science (Erduran \& Dagher, 2014; Kaya, Erduran, Aksoz, \& Akgun, 2019) are derived from the question, "what is science?", which is essentially a question that attempts to demarcate science from other ways of knowing. And this is why the family resemblance conceptualization includes NOSK, knowledge about inquiry, as well as a host of nonepistemic components. The traditional conceptualization of NOSK revolved around characteristics of scientific knowledge (which is why it is called NOSK here) and does not attempt to demarcate science from non-science. It only tries to answer one of the components that answers the question, "What is science?" (Lederman, 2007; Lederman \& Lederman, 2014).

Again, the three part conceptualization of science is easily understood by elementary, middle, and high school students, as well as college students. It is also easily integrated into science classes at all levels. Again, the current purpose of teaching and learning of NOSK, as seen by those in this research filed, is not to argue about the various nuances in the scientific endeavor, but rather discuss the developmental appropriateness and reasonableness of what we ask our students to learn.

The background presented provides an important context for how NOSK is currently conceptualized. Research on NOSK typically focuses on the teaching and learning of knowledge characteristics such as the knowledge being subject to change, the unavoidable element of subjectivity inherent in scientific knowledge, the importance of human creativity as part of scientific knowledge, the empirical basis of scientific knowledge, etc. Clearly, there is no definitive list of characteristics of NOSK. There is a rather extensive body of literature (e.g., Abd-ElKhalick, 2012; Lederman, 2007; Lederman \& Lederman, 2014; Smith, Lederman, Bell, McComas, \& Clough, 1997) addressing the fact that the consensus list of the characteristics of science is by no means perfect and would not be accepted in toto by most philosophers but is widely adopted by science educators as appropriate for introductory science instruction. Clearly, there are different conceptions of NOSK (Kaya et al., 2019), but what is important here is a focus on what students should know and how is it effectively taught (Kampourakis, 2016).

\section{Main section}

\section{Research-based knowledge current teaching practice related to NOSK}

Knowledge of NOSK has been a goal of science education for quite some time (Central Association for Science and Mathematics Teachers, 1907), and has continued to be emphasized in reform documents in seminal reform documents globally For example, Next Generation Science Standards (NGSS Lead States, 2013) and the National Science Education Standards (National
Research Council, 1996). From the U.S., as well as reform documents from all other continents, such as Asia, Australia, Europe, South Africa, and South America (Australian Curriculum and Reporting Authority (ACARA), 2015; Department for Education, 2013; Department of Basic Education (DBE), 2011; MINEDUC, 2012; Ministry of Education, 2011). Nevertheless, the overwhelming empirical literature indicates that NOSK is not being effectively taught in schools. The primary reason for this situation is that NOSK is rarely taught and this is a function of teaches possessing inadequate views of NOSK, let alone how to teach it (Lederman \& Lederman, 2014).

Science educators clearly realize, as well as classroom teachers, that a balance must be achieved between what our students can understand and what our students need to do. And above all it must not be forgotten that NOSK must seamlessly fit within the science curriculum. There are volumes of empirical research that indicate what students can reasonably learn and how NOSK can be effectively taught (Abd-El-Khalick \& Lederman, 2000; Lederman, 1992, 2007; Lederman \& Lederman, 2014). Consequently, a first step, that has generated much discussion among science educators is how do we decide what aspects of NOSK we should emphasize for our students? Given that there are virtually no separate courses on NOSK offered at the pre-college level, instructional emphasis on NOSK must be integrated into the science curriculum, whether it be biology, chemistry, physics, or earth and space science. The following criteria, directly derived from the research literature on nature of scientific knowledge (Lederman \& Lederman, 2014), provide some concrete guidelines that should insure, as much as possible, that development of NOSK understandings can be effectively and pragmatically taught. The NOSK aspects addressed should be:

1. Clearly connected to the science concepts and practices included in the particular science curriculum

2. Developmentally appropriate for students' age, grade level, and abilities

3. Supported by empirical evidence that students can successfully understand the concepts addressed

4. Contain none, or few, contentious claims

5. Clearly connected to the achievement of scientific literacy and students' ability to make informed decisions about global, societal, and personal issues that are science based

It is important to note that although students' decisions about various issues may be contentious, the desire to have students enabled to make such decisions is not a contentious objective. 
The aforementioned criteria provide some guidance in terms of what should and can be taught with respect to NOSK, but this is just one part of the problem. As previously indicated, practicing teachers do not possess adequate understandings of NOSK.

\section{Research on teaching nature of scientific knowledge}

Over the past few decades it has become clear that an explicit, reflective approach to teaching NOSK is more effective than assuming that students will develop understandings simply by doing scientific investigations. The latter approach is generally known as an implicit approach (Abd-El-Khalick \& Lederman, 2000). What has not been made clear, or has been misunderstood by readers of the literature, is what is meant by explicit, reflective teaching of NOSK. For example, some have misrepresented the explicit, reflective approach as the teacher simply pointing out during a lesson or activity where an aspect of NOSK is relevant (Duschl \& Grandy, 2013). Let us be explicit about what it means to be explicit. Explicit does not mean direct instruction or a lecture. The key is asking the types of questions that cause students to reflect on what they have done and concluded within a scientific investigation. For example, while debriefing a class investigation (where students have worked in groups), it becomes clear that not all groups have arrived at the same conclusions. The usual approach to this result in science classrooms is that the teacher conveys that someone must have done something wrong. That is, not everyone arrived at the same desired results. A more accurate approach by the teacher would be to ask the class why everyone did not get the same answer. Naturally, some students will claim that students in dissenting groups did something "wrong." But, the expert teacher should delve further and ask the class for other possible reasons why laboratory groups disagreed. Is it possible that everyone followed the instructions, but did not get the same result? What are some other reasons other than someone did something wrong? Is this also true in science among scientists? Why do they often disagree? Eventually, the discussion will lead to discussions about scientists and students being different people and they interpret data differently. This is why conclusions and scientific knowledge involve subjectivity, creativity, and are always tentative. This is much different than the teacher simply and didactically, as surmised by Duschl and Grandy (2013), telling students that the reason different groups arrived at different conclusions as a result of the aforementioned reasons. In short, aspects of nature of scientific knowledge are brought to the forefront by carefully crafted teacher questions as opposed to a teacher-centered lecture.

Perhaps another example is in order to make our point as explicit as possible. A very popular laboratory activity used by biology teachers while teaching about mitosis is to have students look at onion root tip alium cells and classify the stage of mitosis each of the cells observed is in. Students collect data from three fields of view under the microscope and use the data to eventually calculate the relative time each stage of mitosis takes. It is an unfortunate activity in terms of NOSK and inquiry, but it is nevertheless quite popular. During the debriefing of this activity, the teacher could ask:

1. Why did you use three fields of view instead of five?

2. Did you have difficulty deciding for some cells whether it was in, for example, prophase or interphase?

3. How definite is the separation of one phase from another?

4. Did the same group member do all of the observation of cells or did you divide the work among team members?

5. Does it make a difference that different people or the same people did the observation of cells?

All of these questions can lead to discussions of subjectivity and tentativeness, as well as discussions about scientific inquiry. Again, the teacher never tells the students what is involved, but asks questions that stimulate students to discuss the aspects of NOSK, which are eventually named. It is not didactic and it is not a lecture. This is what is meant by the explicit, reflective approach to teaching NOSK. The content examples used are part of the science curriculum and illustrate way NOSK can be integrated in the curriculum as opposed to requiring a separate course in NOSK. Again, the literature clearly supports an explicit, reflective approach to teaching NOSK. It would be misguided to assume that students will come to understand NOSK simply by doing science investigations. But one can see from these examples there is a logical pedagogical connection between have students experience scientific inquiry and learning about NOSK.

\section{Research on assessing nature of scientific knowledge}

As all science teachers and college science teacher educators should know that what you are teaching must be assessed or student learning is compromised. Students need to know that you value as a teacher is important enough to be assessed and if you do not mention this, they will ask: "Will this be on the test?" Good or bad, it is reality. Comprehensive reviews and support for various assessments of NOSK can be found in Abd-ElKhalick (2014), Lederman (2007), Lederman, Abd-ElKhalick, Bell, and Schwartz (2002). These reviews of assessments directly assess the validity and reliability of the various assessments. 
NOSK can be assessed in a variety of ways, convergent questionnaires, student behaviors, open-ended questionnaires, and interviews. All of these approaches are discussed in Abd-El-Khalick (2014) and Lederman (2007) with the conclusion that interviews and open-ended questionnaires are the most accurate measures of what students know. But, they are labor intensive. We believe that the most effective and pragmatic approach for teachers is to selectively include some of the open-ended questions included in the Views of Nature of Science (VNOS) buffet of assessments in class assessments. In essence, these would constitute essay questions within regular science class assessments or science classroom investigations. If you want to validly assess what students are thinking about higher level concepts, such as NOSK, multiple choice or convergent types of assessments are not adequate. There are some (e.g. Sandoval, 2015) who believe that observing students' behaviors during a science activity is the best way to assess their understandings of NOSK. However, it makes little sense to assume that a student who believes scientific knowledge is tentative will behave any differently while doing a laboratory investigation than a student who believes that scientific knowledge is absolute. The difference between how students behave and what they actually believe is well established with respect to NOSK (Lederman, 2007).

\section{NOSK and challenges for teaching practitioners}

As mentioned in the previous sections on research on the teaching and learning NOSK, teachers do not typically possess adequate understandings of NOSK. This is not because they are unable to understand NOSK, but rather NOSK was not included in their education courses or their science courses or they were not taught how to effectively teach NOSK (Lederman, 1992; Lederman \& Lederman, 2014). It is clear from the empirical research that teachers can learn NOSK and also learn how to effectively teach it to their students. As with many other attempts to transform or change teaching practice, effective professional development must be provided on a continuing basis to both preservice and in-service teachers. The professional development must be based on the best practices delineated by Horsley, Hewson, Love, and Stiles (1998). For good or for worse, classroom instruction is strongly influenced by accountability and high stakes assessments. It is unfortunate, but teachers will be constrained by such assessments until NOSK becomes a consistent outcome that is emphasized along with the typical science concepts. Related to assessment is the overwhelming concern that teachers have about whether giving attention to NOSK will improve students' understandings of traditional subject matter, or worse, decrease their understanding of traditional subject matter. This is an especially strong concern in Asia and other locations that have national curricula with systematic accountability. Finally, the ever expanding science curriculum leaves less and less time for teachers to add other emphases into their instructional plans. This issue circles back to the problem of professional development, which needs to provide extensive attention on how to seamlessly integrate NOSK into the current curriculum. As such, NOSK does not require an unreasonable amount of extra time. It is not an "add on" of something new. In short, this is an issue of the development of pedagogical content knowledge for NOSK. Finally, and admittedly closely related to professional development, is the paucity of materials (e.g., textbooks, readings, curriculum materials) that are available to help teachers learn more about NOSK and support instruction.

\section{Can research help alleviate challenges faced by practitioners?}

There has always been a gap between research and practice. There is also a general feeling by teachers that the empirical research completed by university-based science educators is too theoretical and unrelated to their daily practice and problems. This feeling certainly has merit. However, this situation does not need to continue and it shouldn't. With respect to the teaching and learning of NOSK, the identified challenges can be addressed by research that is both rigorous by any contemporary standards and significantly useful to teachers. The solutions are not easy. Nothing in education is, but not impossible.

\section{Education and science courses}

The initial weak link in establishing an effective and consistent emphasis on NOSK is the emphasis given to the construct in education courses and science courses that preservice and in-service teachers complete as part of their preparation to teach and maintain their licensure to teach. Systematic research can be done on the most effective ways to teach NOSK in education courses. Should the topic be taught as an independent topic or infused with all of the other topics included in a methods course, for example? Prior to addressing instruction in teaching methods courses, there would need to be efforts made and studied on the relative effectiveness of including NOSK in PhD programs for future science education faculty at the university level. Changing the nature of college level science courses is a more elaborate problem. That is, how do you get science specialists and researchers to include NOSK as part of their science courses? It typically is not included, and we also know that scientists typically do not understand NOSK (Abd-El-Khalick, 2001; Lederman, 1992). Consequently, professional development for college science teachers is needed. Research could be done on the relative 
effectiveness of various instructional approaches. However, the most important research would be on effective ways to convince science faculty to transform how they teach science. Transforming college level science teaching is quite difficult and a complex endeavor. Nevertheless, it is an essential component of the solution to the problem at hand.

\section{Professional development}

As mentioned previously, professional development is needed for teachers regarding knowledge of NOSK, the teaching of NOSK, and the assessment of NOSK. Each of these efforts could reasonably be researched with the typical design being an assessment of a particular professional development project. The three areas could be addressed independently or in a combined project.

\section{High stakes assessments}

This area is probably the most difficult to address as it involves politics and policy makers as opposed to just educators. However, one start would be a study of the relative knowledge levels of students in locations that have NOSK on their country or state assessments with those that do not. Is there a difference? Is the level of "traditional" subject matter knowledge different? This could establish a baseline of data to be used to convince policy makers of the efficacy of including NOSK on high risk assessments. The goal would not be to maintain or alleviate high stakes assessments. The goal would be to establish whether the concerns of including NOSK on assessments are beneficial or harmful.

\section{Pedagogical content knowledge and time issues}

Teachers often feel that emphasizing NOSK is additional subject matter to teach in an already full curriculum. But is it? There are different ways to incorporate NOSK into an existing curriculum. Is NOSK truly integrated into the teaching of "traditional" subject matter or is it addressed as a reflective component after instruction on the "primary" subject matter is completed? Are the two approaches equally effective? Are teachers' subject matter knowledge structures altered by the inclusion of NOSK as part of instruction? In what ways are their knowledge structures altered? Are teachers' pedagogical knowledge and instructional practices altered? Does inclusion of NOSK in instruction compromise the effective treatment of "traditional" science subject matter?

\section{Materials and support materials}

Teachers are rarely provided enough of the materials and instructional support they need to enact instructional change. This support and materials range from textbooks to readings, to instructional activities, to peer mentors. All of these supports and materials are important, and they all are potential sources of research that can be assessed and used to alleviate challenges presented to the teacher wishing to integrate NOSK into instruction.

Each of the proposed research projects are admittedly general in nature but address one or more of the challenges experienced by practicing teachers. Although the very minute details of each study are not presented, it should be clear how research specific to each challenge illustrates a way that empirical research can address the problems experienced by the practicing teacher. Of most importance is that what has been recommended is classroom based and not so theoretical that it will be perceived as irrelevant to the classroom teacher.

\section{Research on NOSK at a crossroads}

It is time that we return to the title of this article, and why the term "crossroads" is used for this final discussion. Why is "Déjà vu all over again" embedded in the title of this article? An example from recent reforms in science education in The U.S., which are closely followed by reforms globally should illustrate the point.

The Benchmarks for Science Literacy (AAAS, 1993) emphasized the importance of scientific inquiry and NOSK. Although the Benchmarks claimed to be advocating science instruction that provided an integrated view of the scientific enterprise it was presented as a set of 12 separate chapters. Nature of science (now referred to here as NOSK) was the first chapter in the reform document, and scientific inquiry was presented as a subtopic along with "the scientific world view" and "the scientific enterprise. An important observation is that NOSK was presented separately from the other important student outcomes. NOSK was presented as a separate domain of knowledge. Consequently, it was at least implied that NOSK could or should be taught separately from the other science outcomes. Indeed, it is not uncommon for science teachers to begin the school year with a unit (or several days) dedicated to NOSK and it is fairly typical for science textbooks that address NOSK to have a first chapter on NOSK. And, unfortunately in both of the aforementioned approaches NOSK is never discussed again as instruction delves into the "primary" science concepts of the course.

In 1996 the National Science Education Standards (NSES), "replaced" the Benchmarks as the primary reform document in the United States. "Replaced" has been placed in quotes because there are still many schools and school districts in the U.S. and around the world that still prefer the Benchmarks as their curricular framework for science education. The NSES (NRC, 1996) situated NOSK as a separate domain of knowledge. Although the NSES did a good job of disentangling the conflation of NOSK and SI, the reader was still left with the impression that NOSK could/should be taught as a separate domain of 
knowledge. That is, the NSES was formatted into separate content standards chapters/sections. It can be argued that the NSES was an improvement from the Benchmarks because it recognized that NOSK and SI should be considered as subject matter alongside traditional life, earth and space, and physical science content. In retrospect, although the NSES did separate SI and NOS into two different domains of knowledge, neither the Benchmarks nor the NSES effectively communicated their visions of an integrated approach to the teaching of science. Regardless of this difference, one was hard pressed to see NOSK being taught effectively in science classrooms at any grade level. Nothing was/is really any different today than it was since science educators seriously began studying NOSK in the late 1950s. This is clearly evident in the literature review included in the Handbook of Research on Science Education, Volume II (Lederman \& Lederman, 2014).

With much anticipation and fanfare, the Next Generation Science Standards (NGSS) was made public in 2013 (NGSS Lead States, 2013). The NGSS strongly emphasizes an integrated approach to science teaching and learning across three dimensions: Science and Engineering Practices, Disciplinary Core Ideas, and Crosscutting Ideas. The latter is clearly the most attentive to themes that run across all of the sciences, but the idea is that a concerted effort be made to include all three dimensions in all instructional planning and instruction. Most important to the present discussion is that the NGSS positions NOSK as a subset of the dimensions of Science Practices and Crosscutting Concepts. Specifically, NOSK is considered to be constituted by eight understandings. Those understandings related to Science Practices are:

- Scientific Investigations Use a Variety of Methods

- Scientific Knowledge is Based on Empirical Evidence

- Scientific Knowledge is Open to Revision in Light of New Evidence

- Science Models, Laws, Mechanisms, and Theories Explain Natural Phenomena

Those understandings associated with Crosscutting Concepts are:

- Science is a Way of Knowing

- Scientific Knowledge Assumes an Order and Consistency in Natural Systems

- Science is a Human Endeavor

- Science Addresses Questions About the Natural and Material World

There was a need for further clarification of the NGSS vision with respect to a variety of issues, one of which was the lack of emphasis on NOSK. The distribution of ideas commonly associated with NOSK is divided across two dimensions in a manner that, once again, conflates SI and NOSK. So, in one way, there has been a step back to the conflation evident in the Benchmarks. However, the way NOSK has been situated, in the NGSS, is a bit more complex. That is, NOSK is positioned as a subset of Science Practices (i.e, the doing of science), however understandings about inquiry/practices (NOSI) are positioned as a subset of NOSK. The NSES was prominent in its recognition that there was a difference between outcomes concerning students "doing" of science (e.g., observing, inferring, concluding, etc.) and knowledge "about" inquiry (NOSI) (e.g., there is no single scientific method, all investigations begin with a question, but not necessarily a hypothesis). The NGSS has placed the "doing" of science as part of the Practices and the knowledge "about" inquiry as a subset of NOSK. On the positive side, the treatment of NOSK as a separate domain of knowledge in both the Benchmarks and NSES is not evident in the NGSS. Consistent with the integrated vision of the NGSS, NOSK has been integrated within the subject matter outcomes as opposed to a separate domain of knowledge. This definitely implies a curricula direction that was not achieved by either the Benchmarks or NSES. Presumably, there will be no attempt to have teachers develop separate units or lessons for NOSK. However, a serious concern has been created. NOSK, is merely mentioned as a "connection" that teachers can make as opposed to an explicit standard. Students' understandings of NOSK have no performance expectations stated and so there is no reason to believe that understandings of NOSK will be explicitly taught or assessed. It is well established that teachers typically do not teach what is not assessed (Dwyer, 1998). Overall, in the NGSS, NOSK is relegated to the position of a "connection," which teachers may choose to make or not. There is no real encouragement for teachers to embed NOSK in NGSS aligned lessons.

The NGSS contains no explicit standards or performance expectations for NOSK (i.e., only "connections" are specified). It appears that the writers of the NGSS have assumed that students will come to understand NOSK simply by engaging in science practices and learning about crosscutting concepts. However, the overwhelming body of empirical research, as reported in the following comprehensive reviews of the empirical literature, indicates that students will not develop informed views of NOSK if it is not explicitly integrated into instruction (Abd-El-Khalick \& Lederman, 2000; Lederman, 2007; Lederman \& Lederman, 2014). Again, "Explicit" should not be mistakenly considered as synonymous with direct instruction, as some have previously assumed (Duschl \& Grandy, 2013). It simply means that NOSK is brought to the forefront at various times during instruction through discussions and reflections among the students. Perhaps, 
the word "intentional" is a more accurate description than "explicit" with respect to NOSK. Bringing NOSK to the forefront during instruction goes well beyond the teacher pointing out aspects of NOSK when appropriate, but rather involves students reflecting on their experiences as they struggle with developing science understandings as they engage with phenomena. In summary, how SI and NOSK are contextualized and related has significant implications for curriculum outcomes and instructional practice. If NOSK is embedded implicitly within an SI focus, instruction will focus on students doing SI and NOSK will be learned by chance, if learned at all. Although the NGSS has progressed from the conflation and isolated attention to SI and NOSK, they represent a step backward in terms of what empirical research tells us about how students come to learn about NOSK, and eventually become scientifically literate. The shifting contextualization of SI and NOSK in the reform efforts in the U.S. was used as an example, to illustrate the crossroads we are at, but the concern applies to reforms and curricula worldwide.

We are at a crossroads because we have, in the U.S., regressed to what was believed in the 1960s. That is, students learn about NOSK implicitly simply by doing science. Our international colleagues are urged to not so willfully assume that reform documents from the U.S. are based on the most informed research and should be followed without critical analysis. With respect to NOSK, the NGSS appears to be less than informed. For the same reason we are at Déjà vu because we have believed the same thing many years ago. This is all compounded by the fact that science educators have now chosen to distract themselves about how to define NOSK (i.e., what should be included and omitted from the construct) instead of focusing on what students need to know and be able to do, as opposed to how it is labeled.

\section{Conclusion}

Moving forward: what research needs to be done?

Although NOSK (alternatively NOS) has been a focus of systematic empirical research for almost 70 years, there are many unanswered questions that can contribute to the solutions of the challenges that teachers face. Additionally, although there exists fairly robust knowledge about the teaching and learning of NOSK, there remain many important unanswered questions. What follows is a brief listing and explanation of the important questions that remain unanswered.

\section{How can we facilitate teachers' valuing of NOSK to the point where it has equal status with the more "traditional" science subject matter?}

It is often the case that teachers with informed views of NOSK and the ability to effectively teach NOSK, do not address NOSK in their classroom practice. Sometimes it is felt that the abstract concept of NOSK goes above and beyond the developmental level of the students being taught. At other times, teachers under value NOSK learning because it is not stressed on high stakes tests. Related to high stakes tests is the feeling that attention to NOSK takes time away from the study of science topics that are stressed on high stakes tests. In depth studies are needed that focus on teachers' beliefs and motivation to address NOSK in classroom settings. What impacts teachers' beliefs and motivation in this area? What motivates teachers to persist in their attempts to teach NOSK? How can teachers overcome pressure from the school culture and peers that may not value NOSK?

\section{Does knowledge of NOSK facilitate understandings of "traditional" science subject matter?}

One of the often stated assumptions and rationales for why NOSK is important is that understanding NOSK increases science achievement. Unfortunately, this has not been empirically demonstrated. Studies are needed that correlate NOSK understanding and science achievement. Such correlational studies could lead to more experimental studies that establish a causal relationship between NOSK knowledge and science achievement.

Does instructional time spent on NOSK detract from students' learning of "traditional" subject matter? In locations where high stakes testing is emphasized (e.g., Asia) parents, teachers, and administrators believe that adding NOSK to the curriculum and instruction will decrease the time spent on the knowledge that is stressed on high stakes tests, resulting in lower test scores. Indeed, this is the polar opposite of what was addressed in the previous research question. Empirical studies are clearly needed that may demonstrate that when students do learn NOSK it does not negatively impact their performance on high stakes tests. Without such research there will remain a high resistance to integrate NOSK into science curriculum and instruction.

\section{Are all explicit/reflective approaches to NOSK instruction of equal effectiveness?}

As previously discussed, researchers have known for several decades that explicit/reflective instruction is superior to the previously supported implicit approaches. However, there is a dearth of studies that compare different explicit/reflective approaches. Explicit/reflective approaches that have been shown to effectively enhance students' learning of NOSK include inquiry activities, demonstrations, use of socioscientific issues as an instructional platform, use of history of science, and even direct instruction. Are all of these approaches equally effective or is a combination best? 


\section{Is NOSK best taught through stand along instructional} activities or integrated within subject matter instruction? Intuitively, it has long been felt that the full integration of NOSK with more "traditional" subject matter is more effective. However, a close examination of the literature provides ambivalent findings. Certainly, this is a question that needs further research.

\section{How enduring are teachers' and students' understandings of NOSK?}

Often the understandings of NOSK that students and teachers develop fade away quickly, unless there is constant and continuing support from a professional developer or fellow science teacher. Are these supports equally effective? Are there other supports that are less expensive and time consuming? Research needs to be completed that facilitates long-term retention of NOSK understandings.

\section{Does understanding of NOSK impact students' decisions regarding personal, societal, and global issues?}

One of the enduring justifications for inclusion of NOSK in the curriculum is that it informs students' decision making. However, to this date, this relationship has not been documented. Perhaps the only study that has focused on NOSK and decision making was by Bell and Lederman (2003). That study found no significant relationship. The authors speculated that it may be necessary to teach students how to use NOSK when making decisions, as opposed to assuming that students would naturally use whatever understandings of NOSK they possess to inform their decisions. Research in this area is important and clearly needed. This is especially important to those who favor the use of socio scientific issues as a platform for the learning of NOSK and science subject matter.

\section{Where have we been and where are we going?}

The longevity of understanding NOSK as a valued instructional objective in science education has continued for over a century. Arguably, its recognized importance continues to increase worldwide (with the exception of the U.S. NGSS). We have progressed from the faulty assumption that students and teachers will come to understand NOSK simply by doing science to the recognition that NOSK needs to be planned for and explicitly addressed in instruction, just like any other valued science knowledge. NOSK is recognized as a critical component of scientific literacy, and its associated understandings are abstract and complex. Yes, there is a lot of work left to do. Consequently, the research community must maintain its vigilance to the task at hand. Debates and protracted discussions about what should be included under the construct label of NOSK (i.e., consensus views vs. family resemblance) will ultimately be unproductive. Our focus should be on what we want students to know, and not the labels we decide to which we ascribe meaning.

\section{Acknowledgements}

NA.

Authors' contributions

$\mathrm{NL}=80 \%$. $J \mathrm{~L}=20 \%$. Both authors read and approved the final manuscript.

Funding

NA.

Availability of data and materials

NA.

Competing interests

The authors declare that they have no competing interests.

Received: 7 May 2019 Accepted: 6 July 2019

Published online: 28 November 2019

\section{References}

American Association for the Advancement of Science. (1993). Benchmarks for science literacy. New York: Oxford University Press.

Abd-El-Khalick, F. (2001). Embedding nature of science instruction in preservice elementary science courses: Abandoning scientism, but ... Journal of Science Teacher Education, 12(3), 215-233. https://doi.org/10.1023/A: 1016720417219.

Abd-El-Khalick, F. (2012). Examining the sources for our understandings about science: Enduring conflations and critical issues in research on nature of science in science education. International Journal of Science Education, 34(3), 353-374. https://doi.org/10.1080/09500693.2011.629013.

Abd-El-Khalick, F. (2014). The evolving landscape related to assessment of nature of science. In N. G. Lederman, \& S. K. Abell (Eds.), Handbook of research on science education, (vol. II, pp. 621-650). Mahwah: Lawrence Erlbaum. https:// doi.org/10.4324/9780203097267.

Abd-El-Khalick, F., \& Lederman, N. G. (2000). Improving science teachers' conceptions of the nature of science: A critical review of the literature. International Journal of Science Education, 22(7), 665-701. https://doi.org/10. 1080/09500690050044044.

Australian Curriculum and Reporting Authority (ACARA) (2015). Australian curriculum: Science F-10. Sydney: Commonwealth of Australia.

Bell, R. L., \& Lederman, N. G. (2003). Understandings of the nature of science and decision making in science and technology based issues. Science Education, 87(3), 352-377. https://doi.org/10.1002/sce.10063.

Central Association for Science and Mathematics Teachers (1907). A consideration of the principles that should determine the courses in biology in secondary schools. School Science and Mathematics, 9(3), 241-247. https:// doi.org/10.1111/j.1949-8594.1909.tb03028.x.

Department for Education. (2013). The national curriculum of England: Science Programmes of Study. Retrieved from https://www.gov.uk/government/ publications/national-curriculum-in-england-science-programmes-of-study/ national-curriculum-in-england-science-programmes-of-study

Department of Basic Education (DBE) (2011). Curriculum assessment policy statement grades 7-9, natural sciences. Pretoria: Department of Basic Education.

Duschl, R. A., \& Grandy, R. (2013). Two views about explicitly teaching nature of science. Science \& Education, 22(9), 2109-2139. https://doi.org/10.1007/ s11191-012-9539-4.

Dwyer, C. A. (1998). Assessment and classroom learning: Theory and practice. Assessment in Education: Principles, Policy \& Practice, 5(1), 131-137. https://doi. org/10.1080/0969595980050109.

Erduran, S., \& Dagher, Z. R. (2014). Reconceptualizing the nature of science for science education. Dordrecht: Springer.

Feynman, R. P., \& Cashman, D. (2013). The pleasure of finding things out. Blackstone Audio, Incorporated.

Horsley, S., Hewson, P. W., Love, N., \& Stiles, K. E. (1998). Designing professional development for teachers of science and mathematics. Thousand Oaks: Corwin Press Inc.

Kampourakis, K. (2016). The "general aspects" conceptualization as a pragmatic and effective means to introducing students to nature of science. Journal of Research in Science Teaching, 53(5), 667-682. https://doi.org/10.1002/tea. 21305. 
Kaya, E., Erduran, S., Aksoz, B., \& Akgun, S. (2019). Reconceptualized family resemblance approach to nature of science in pre-service science teacher education. International Journal of Science Education, 41(1), 21-47. https://doi. org/10.1080/09500693.2018.1529447.

Kuhn, T. S. (1970). The structure of scientific revolutions. Chicago: University of Chicago Press.

Lederman, N. G. (1992). Students' and teachers' conceptions of the nature of science: A review of the research. Journal of Research in Science Teaching, 29(4), 331-359. https://doi.org/10.1002/tea.3660290404.

Lederman, N. G. (2007). Nature of science: Past, present, and future. In S. K. Abell, \& N. G. Lederman (Eds.), Handbook of research on science education, (pp. $831-$ 880). Mahwah: Lawrence Erlbaum Associates.

Lederman, N. G., Abd-El-Khalick, F., Bell, R. L., \& Schwartz, R. S. (2002). Views of nature of science questionnaire: Toward valid and meaningful assessment of learners' conception of nature of science. Journal of Research in Science Teaching, 39(6), 497-521. https://doi.org/10.1002/tea.10034.

Lederman, N. G., \& Lederman, J. (2014). Research on teaching and learning of nature of science. In N. G. Lederman, \& S. K. Abell (Eds.), Handbook of research on science education, (vol. II, pp. 600-620). New York: Routledge. https://doi.org/10.4324/9780203097267.ch30.

MINEDUC (2012). Bases Curriculares Educación Básica. Santiago: Ministerio de Educación.

Ministry of Education (2011). Science curriculum standard for full-time schools of compulsory education (2011 version). Beijing: Beijing Normal University Press.

National Research Council (NRC). (1996). National science education standards. Washington, DC: National Academies Press. https://doi.org/10.17226/4962.

NGSS Lead States (2013). Next generation science standards: For states, by states. Washington, DC: The National Academies Press. https://doi.org/10.17226/ 18290

Rubba, P., \& Anderson, H. (1978). Development of an instrument to assess secondary student's understanding of the nature of scientific knowledge. Science Education, 62(4), 449-458. https://doi.org/10.1002/sce.3730620404.

Sandoval, W. A. (2015). Understanding students' practical epistemologies and their influence on learning through inquiry. Science Education, 89(5), 634-656. https://doi.org/10.1002/sce.20065.

Smith, M. U., Lederman, N. G., Bell, R. L., McComas, W. F., \& Clough, M. P. (1997). How great is the disagreement about the nature of science: A response to alters. Journal of Research in Science Teaching, 34(10), 1101-1103 https://doi. org/10.1002/(SICI)1098-2736(199712)34:10<1101::AID-TEA8>3.0.CO;2-V.

\section{Publisher's Note}

Springer Nature remains neutral with regard to jurisdictional claims in published maps and institutional affiliations.

\section{Submit your manuscript to a SpringerOpen ${ }^{\circ}$ journal and benefit from:}

- Convenient online submission

- Rigorous peer review

- Open access: articles freely available online

- High visibility within the field

- Retaining the copyright to your article

Submit your next manuscript at $\boldsymbol{\nabla}$ springeropen.com 